\title{
Vaccine sought as bird flu infects humans
}

David Cyranoski, Tokyo

A bird flu virus is the subject of intense scrutiny amid fears that it could spark a human flu pandemic. Virologists increased their vigilance after the avian virus infected two people in Hong Kong last month.

Flu pandemics, which can kill millions of people, are thought to arise when viruses carried by animals — often birds - form hybrids with viruses that can transfer readily between humans.

It is difficult to predict when this will occur, virologists say, but the cases in Hong Kong - a 33-year-old man who died on 17 February and his 9-year-old son, who is in a stable condition - have focused attention on an avian flu strain called H5N1. Initial examination of the strain suggests that, at the moment, it cannot move easily from human to human. "Fortunately, this is purely avian," says Malik Peiris, a microbiologist at the University of Hong Kong.

But health officials are nonetheless rushing to prepare a vaccine to control the spread of $\mathrm{H} 5 \mathrm{~N} 1$ among humans. Some are also

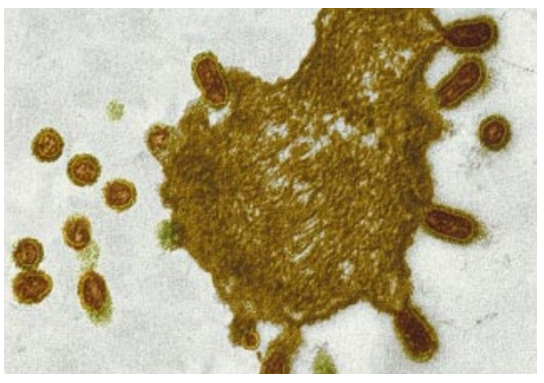

Virologists fear that the H5N1 virus, shown bursting from a cell, could trigger a pandemic.

alarmed about an inadequately understood outbreak of respiratory illness that has killed several people in the nearby Chinese province of Guangdong - although no link has been confirmed between this and the avian flu.

Flu viruses are constantly mutating, often exchanging DNA with other similar viral strains. It was hybrids between avian and human influenza viruses that led to the last two flu pandemics, in 1957 and 1968. H5N1 has a worrying track record - it was not

\section{India budgets for boost in research}

\section{K. S. Jayaraman, New Delhi}

India has cheered its research community by announcing increases in research funding as part of a generally austere budget.

In the financial year that begins on 1 April, the government plans to spend Rs147 billion (US\$3.1 billion) on research and development (R\&D) - an increase of about 9.5\% - despite an economic slowdown that was exacerbated by the failure of the rains in last year's monsoon.

"The drought may have axed some projects in other ministries, but not in ours," Valangiman Ramamurthi, secretary of science and technology, told Nature.

"The jump is not as big as last year's 25\%," says Ragunath Mashelkar, a chemical engineer who runs several of the ministry's applied research labs, "but it is adequate".

The rise reflects the government's ambitious plan to expand India's total R\&D spending from $1.1 \%$ of gross national product to $2 \%$ by 2007 , says Ramamurthi. The funding hike comes despite the fact that the government has allotted only Rs60 billion in new money to all of its ministries this year.

Ramamurthi points to injections of an extra Rs2.15 billion for multidisciplinary research projects and Rs1.5 billion for drug research as examples of the government's priorities. The latter is being given priority, government officials say, so that India can

\begin{tabular}{|c|c|c|}
\hline \multicolumn{3}{|c|}{ India's R\&D spending, millions of rupees } \\
\hline Item & 2002-03 & 2003-04 \\
\hline Agriculture & 14,490 & 15,110 \\
\hline Atomic energy & 33,520 & 38,010 \\
\hline Information technology & 5,020 & 5,020 \\
\hline Medical research & 9,330 & 9,880 \\
\hline Ocean research & 1,740 & 1,990 \\
\hline Dept Science and Technology & 9,320 & 11,760 \\
\hline Industrial research & 9,850 & 11,360 \\
\hline Biotechnology & 2,210 & 2,730 \\
\hline Space & 21,630 & 23,680 \\
\hline Defence & 27,000 & 27,340 \\
\hline Total & 134,110 & 146,880 \\
\hline
\end{tabular}

develop its own drugs when the copying of foreign ones is outlawed by a new patent regime that is scheduled to come into force in 2005.

Biotechnology, information technology and renewable-energy research all rank highly in the budget, which also earmarks funds for a controversial plan to build a fast-breeder nuclear reactor near Chennai in Tamilnadu state.

"Overall, the budget is very good," says Debi Sarkar, a biochemist at Delhi University. "I have much more money for my projects than when I started my career six years ago and I have no complaints." But he adds that the main problem faced by Indian researchers "has never been with money, but with bureaucracy". supposed to cross over from birds directly to humans, but in 1997 it infected a few hundred people in Hong Kong, killing six of them.

Moreover, the latest strain is genetically distinct from that of 1997. Between the two strains, only one gene - for the protein haemagglutinin — is similar. "Over the past five years, the $\mathrm{H} 5 \mathrm{~N} 1$ virus has been moving around southeast Asia picking up new genes," says Klaus Stöhr, director of the global influenza network run by the World Health Organization (WHO) in Geneva.

Clearly, H5N1 can infect and kill people, so if it develops the capacity to move easily from human to human, it could conceivably cause a pandemic. The virus could gain this ability either by adapting itself through genetic mutations once inside the body, or by mixing with a widely circulating human flu strain, such as $\mathrm{H} 3 \mathrm{~N} 2$, in someone infected with both viruses, says Stöhr. "We have to watch it closely."

The threat has pushed the WHO to accelerate its vaccine development. At an emergency meeting last week in Geneva, researchers discussed the problems involved in developing a vaccine against $\mathrm{H} 5 \mathrm{~N} 1$.

Flu vaccines are normally made by injecting viruses into hens' eggs and letting them multiply as the embryo develops. But the $\mathrm{H} 5 \mathrm{~N} 1$ virus, being an avian flu, kills the chick embryos. So selected genes from the virus are instead inserted into a different flu virus before it is injected into the eggs.

If all goes well, a vaccine could be designed within four to six weeks if it is needed, says Ian Gust, director of the WHO collaboration centre for influenza at the University of Melbourne, Australia. Animal tests, quality control and manufacturing, however, would take several more months, raising the danger that a pandemic could occur before the vaccine was available to control it.

Many researchers suspect that the latest $\mathrm{H} 5 \mathrm{~N} 1$ strain originated in mainland China, which has led to increased interest in the respiratory illness sweeping Guangdong. China has so far not invited external parties to visit the province. "We would like to support China in terms of surveillance and disease definition, but we haven't been invited in," says Nikki Shindo, medical officer for the WHO's global influenza programme.

Beijing has told the WHO that the epidemic was caused by the bacterium Chlamydia pneumoniae and is now under control. "But that can't be the whole story," says a Chinese researcher close to the investigation of the outbreak. "From a clinical standpoint, it seems to be related to a virus, and we cannot rule out the bird flu."

Researchers say that the data do not exist to prove or disprove any link. "We don't know," says Gust. "We need careful molecular and epidemiological studies." 